\title{
Anti-inflammatory activity of Vismia guianensis (Aubl.) Pers. extracts and antifungal activity against Sporothrix schenckii
}

\author{
A.H. Oliveira ${ }^{\mathrm{a}}$, G.G. de Oliveira ${ }^{\mathrm{b}}$, F. Carnevale Neto ${ }^{\mathrm{b}}$, D.F. Portuondo ${ }^{\mathrm{a}}$, A. Batista-Duharte ${ }^{\mathrm{a}}$, \\ I.Z. Carlos ${ }^{\mathrm{a}, *}$ \\ ${ }^{\text {a }}$ Faculdade de Ciências Farmacêuticas. Universidade Estadual Paulista Julio Mesquita Filho, UNESP, Rod. Araraquara-Jaú - Km 1 -s/n -CEP: 14800-903, \\ Araraquara, SP, Brazil \\ b Faculdade de Ciências Farmacêuticas de Riberão Preto, Universidade Estadual de São Paulo, Departamento de Física e Química, Riberão Preto, SP, Brazil
}

\section{A R T I C L E I N F O}

\section{Keywords:}

Antifungal

Anti-inflammatory

Vismia guianensis

Prenylated benzophenone, Sporothrix

schenckii

Sporotrichosis

\begin{abstract}
A B S T R A C T
Ethnopharmacological relevance: Vismia guianensis (Aubl.) Pers. is traditionally used in North and Northeast of Brazil for the treatment of dermatomycoses. Since the strategy associating immunomodulators with antifungal drugs seems to be promissory to improve the treatment efficacy in fungal infections, we aimed to investigate the antifungal activity of $V$. guianensis ethanolic extract of leaves (VGL) and bark (VGB) against Sporothrix schenckii ATCC 16345 and their antinflammatory activities.

Material and methods: The extracts were analyzed by HPLC-DAD-IT MS/MS for in situ identification of major compounds. Antifungal activity was evaluated in vitro (microdilution test) and in vivo using a murine model of S. schenckii infection. The production of TNF- $\alpha$, IFN- $\gamma$, IL-4, IL-10 and IL-12 by measured by ELISA, as well as measured the production and inhibition of the NO after treatment with the plant extracts or itraconazole (ITR). Results: Two O-glucosyl-flavonoids and 16 prenylated benzophenone derivatives already described for Vismia were detected. Both VGL and VGB showed significant antifungal activity either in in vitro assay of microdilution $(\mathrm{MIC}=3.9 \mu \mathrm{g} / \mathrm{mL})$ and in vivo model of infection with reduction of $S$. schenckii load in spleen. It was also observed a predominance of reduction in the production of $\mathrm{NO}$ and the proinflammatory cytokines evaluated except TNFa, but with stimulation of IL-10, as evidence of a potential anti-inflammatory effect associated. Conclusion: The results showed that both VGL and VGB have a significant antifungal against S. schenckii and an anti-inflammatory activity. These results can support the use of these extracts for alternative treatment of sporotrichosis.
\end{abstract}

\section{Introduction}

Besides being holder of the largest diversity, estimated at $20-22 \%$ of the world total (over 45,000 species), Brazil has a rich cultural diversity and ethnic resulting in considerable accumulation of knowledge and technology traditional, passed from generation to generation, highlighting the vast range of knowledge about the management and use of medicinal plants. However, the market for plant-derived drugs in this country (phytomedicines) is still very small, representing less than $5 \%$ of all marketed drugs. Therefore, studies approaching mechanistic aspects, safety, pharmacokinetics and clinical aspects are necessary to make it possible to develop new plant-derived drugs and herbal medicines in the future (Dutra et al., 2016).

Despite recent advances in antifungal therapy for opportunistic mycosis, there are still many unresolved aspects, regarding the long lasting therapy regimen, fungal resistance and toxicity, leading to sub- therapeutic antifungal drug concentrations and poorer clinical outcomes (Chau et al., 2014). The limited number of treatment options, joint to the increasing frequency of cross-resistance, makes necessary to develop new therapeutic strategies against fungal invasive infections. Some of these strategies are based in the improving of the antifungal effect and the stimulation of the immune response (Portuondo et al., 2015; Batista-Duharte et al., 2016). Many efforts have been made to evaluate the antifungal properties of different medicinal plants with the hope of discovering new and more efficient antifungal compounds as therapeutic alternative to classic chemotherapy. These studies have proven the effectiveness of certain plant extract and essential oil in treating fungal infections. (Cruz et al., 2007; Svetaz et al., 2010; Uma et al., 2016).

Vismia guianensis (Aubl.) Pers, popularly known as "lacre", paude-lacre, árvore-da-febre, caapiá e caopiá, belongs to the family Clusiaceae (also named Guttiferae). The plant is commonly found in

\footnotetext{
* Correspondence to: Faculty of Pharmaceutical Sciences of Araraquara, Universidade Es tadual Paulista Julio Mesquita Filho, UNESP, Araraquara, São Paulo CEP:14801-902, Brazil.
} 


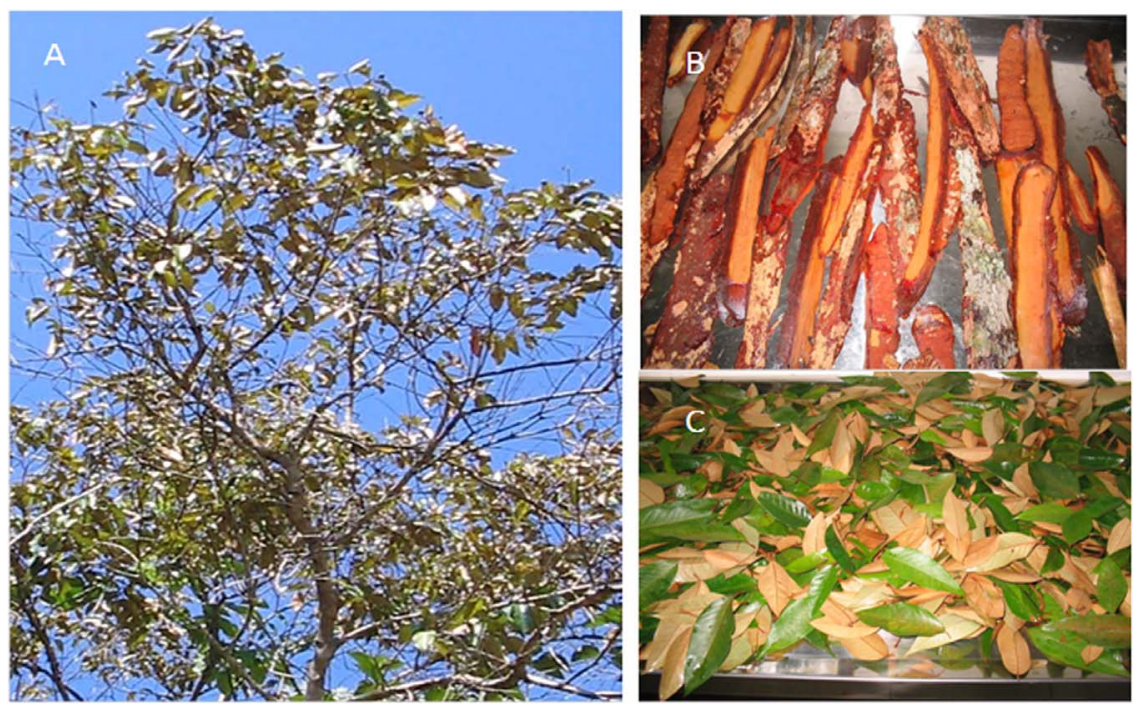

Fig. 1. Vismia guianensis (Aubl.) Pers Aerial parts, leaves and stem bark.

countries and regions of Tropical America, such as: Colombia, Venezuela, Guyana and different areas of North and Northeast Brazil (Almeida-Cortez and Melo-de-Pinna, 2006). It is a shrub or small tree, with oval leaves, oblong, inflorescence in terminal panicles and fruits globose, fleshy indehiscent (Fig. 1). The latex (yellow-red resin called gum or gum-gutta seal) and the infusion of the leaves, are used in the treatment of dermatomycoses, and other applications such as purging. The decoction and infusion of its leaves and husks are also used for rheumatism, and as a tonic febrifuge. Several studies have indicated that Vismia species extracts can exhibit important antibacterial, antifungal, antiparasitic, insecticides, and antivirals properties that have been used by indigenous populations to treat diverse diseases. Regarding the antifungal properties, it was reported that the Wayãpi tribe living in French Guyana, use latex bark to treat oral fungal infections in children (Vizcaya et al., 2012). As support of this finding, Kuete et al., 2007, reported the in vitro antifungal effect of Vismia laurentii against Candida albicans y Candida gabrata, while Tamokou et al. (2009), showed the antifungal activities of the methanol crude extract and several isolated compounds of $V$. rubescens against $C$. albicans, Candida tropicalis, Candida parapsilosis and Cryptococcus neoformans. This finding supports the traditional use of this plant in the treatment of several infectious diseases (Hussain et al., 2012).

Sporotrichosis (also known as "rose gardener's disease") is a deep cutaneous mycotic infection caused by the dimorphic fungus Sporothrix schenckii, formed by a complex of clinically relevant species: $S$. brasiliensis, $S$. globosa, $S$. mexicana in addition to $S$. schenckii s. str. and S. luriei (Mora-Montes et al., 2015). Sporotrichosis has gained importance in recent years due to its worldwide prevalence, recognition of multiple cryptic species within the originally described species, and its distinctive ecology, distribution, and epidemiology across the globe. This disease is currently known emergent mycoses in several tropical and subtropical countries (Chakrabarti et al., 2015; Carlos and Batista-Duharte 2015). The fungal resistance to different environmental conditions and their adaptation to the host, are determinant for the dissemination and virulence of the different species (Téllez et al., 2014), while the host immunity determinate the clinical form of the disease (Gutierrez-Garrardo et al., 2015).

Itraconazole (ITR) is currently considered the drug of choice to treat the vast majority of clinical cases of sporotrichosis, while amphotericin B is the first choice for the treatment of disseminated and severe cases. However, the antifungal therapy often is associated to toxicity and fungal resistant associated to long lasting therapy. (BatistaDuharte et al., 2015). Accordingly, the search of alternative methods for the sporotrichosis treatment is a matter of great current interest.
Diverse formulations from various types of plants have been evaluated against Sporothrix species in different parts of the world. These studies evidenced the enormous potential of these natural preparations as alternative treatment against sporotrichosis (Johann et al., 2007; Apisariyakul et al., 1995; Stopiglia et al., 2011; Gaitán et al., 2011; Singh et al., 2008; Masoko et al., 2005, 2010; Waller et al., 2016). In addition, some recent evidences suggest that association of immunomodulation and the antifungal effect can improve the efficacy of the sporotrichosis treatment (Guterres et al., 2014; Batista-Duharte et al., 2016).

Taking in mind the reported antifungal effects of Vismia genus in Candida species and that until now there are no reports of the effect of $V$. guianensis in sporotrichosis, the aim of this study was to identify the bioactive constituents from the ethanol extract of leaves and bark from $V$. guianensis (Aubl.) Pers and investigate the antifungal and antiinflammatory activities against $S$. schenckii.

\section{Materials and methods}

\subsection{Collection and identification of plant materials}

The plant materials composed of stem bark (VGB) and leaves (VGL) of $V$. guianensis (Aubl.) Pers. was collected in the urban area of the city of Manaus-AM, in the premises of the campus of the Federal University of Amazonas, from December to January 2009. Fertile representatives were collected for the production of voucher specimen has been identified and deposited in the Herbarium of the National Institute for Amazonian Research - INPA. A voucher specimen was registered under number 213331.

\subsection{Preparation of plant extracts}

Either stem bark or leaf powder of $V$. guianensis (Aubl.) Pers. were differently soaked in ethanol: water as solvent solution at $10 \%(\mathrm{w} / \mathrm{v})$. The mixture was agitated using an electric blender (to enhance proper mixing of the solvent with the powder), and then kept by 7 days in dark-coloured flasks with occasional stirring. The liquid phases were filtered through Whatman No. 1 filter paper and residue was reextracted with equal volume of solvents and renewal of liquid extractor. Combined supernatants were evaporated under vacuum at $40{ }^{\circ} \mathrm{C}$ using rotary evaporator and then lyophilized. The obtained extracts were kept in sterile sample tubes and stored in a refrigerator at $4{ }^{\circ} \mathrm{C}$. 


\subsection{Phytochemical screening}

The VGB and VGL extracts were evaluated by phytochemical qualitative reactions for usual plant secondary metabolites. The screening was performed for anthraquinones, flavonoids, saponins, tannins, and alkaloids. The colour intensity or the precipitate formation was used as analytical responses to these tests (Pochapski et al., 2011).

\subsection{Chromatographic analysis of plant extracts}

Ten milligrams of freeze-dried VGL or VGB extracts were solubilized in a water/methanol solution $(8: 2 \mathrm{v} / \mathrm{v})$ for high performance liquid chromatography coupled with diode array detector and ion trap mass spectrometry with electrospray source (HPLC-DAD-ESI-IT MS/ MS). Chromatography separation was performed using Shimadzu LC20A with DAD CBM20A; Shimadzu coupled to the mass spectometer Amazon SL Bruker Daltonics. The mobile phase was $\mathrm{MeOH}$ (B) and $\mathrm{H} 2 \mathrm{O}$ (A) containing $1.0 \%$ de acetic acid (v/v), in elution gradient: $0.01 \mathrm{~min}: 5.0 \%$ B, $45.0 \mathrm{~min}: 100.0 \%$ B, $50.0 \mathrm{~min}: 100.0 \%$ B, $55 \mathrm{~min}$ : $5.0 \%$ B, $60.0 \mathrm{~min}: 5.0 \%$ B. It was used a column Luna C-18 $(4.6 \times 250.0 \mathrm{~mm}, 5 \mu \mathrm{m}$, Phenomenex), flow of $1.0 \mathrm{~mL} / \mathrm{min}$, temperature: $35^{\circ} \mathrm{C}$, injection volume: $20 \mu \mathrm{L}$, pressure limits (A and B), $0-350$ $\mathrm{Kgf} / \mathrm{cm} 2$, collision gas $\mathrm{N} 2$ and collision energy amplitude $60 \%$. The analyses were performed through Bruker DataAnalysis 4.2 software.

\subsection{Microorganism and culture conditions}

S. schenckii ATCC 16345, originally obtained from a human case of diffuse lung infection (Baltimore, MD) and kindly provided by the Oswaldo Cruz Foundation (Rio de Janeiro, Brazil), was used for all experiments. For mice infection, a piece of the fungal mycelium grown on Mycosel (BD Biosciences) agar tubes was transferred to an Erlenmeyer flask containing $100 \mathrm{~mL}$ of brain-heart infusion broth (Difco) and then cultured for 7 days at $37^{\circ} \mathrm{C}$ with constant shaking at $150 \mathrm{rpm}$. After that, an aliquot containing $2 \times 10^{7}$ yeast cells was transferred to a new medium and cultured for 5 days more at the same conditions in order to achieve a virtually $100 \%$ mycelium-to-yeast conversion in a logarithmically growing culture.

\subsection{In vitro antifungal activity}

\subsubsection{Determination of minimum inhibitory concentration (MIC)}

The minimum inhibitory concentration (MIC) was performed according to the procedures recommended for the fungal yeast forms. (Clinical and Laboratory Standards Institute 2008). The antifungal activity was detected by the Microplate Alamar Blue assay (MABA). It is a colorimetric method using Alamar Blue oxido-reducing substance as an indicator of microbial growth and it is useful for dimorphic fungi (de Paula e Silva et al., 2013), including S. schenckii (Batista-Duharte el at. 2016). Briefly, $100 \mu \mathrm{L}$ of each extracts or ITR were added by well, separately (in triplicate) and the concentrations in RPMI 1640 ranged from 500 to $0.000875 \mu \mathrm{g} / \mathrm{mL}$ and 16 to $0.00003 \mu \mathrm{g} / \mathrm{mL}$ for ITR. After that $100 \mu \mathrm{L}$ of the prepared fungal suspension $\left(1 \times 10^{3}\right.$ to $5 \times 10^{3} \mathrm{CFU} /$ $\mathrm{mL}$ ) was added to each well of 96-well microtiter plates containing. Growth and sterility controls were included for each isolate tested (growth control: RPMI medium with DMSO and organisms but with no drug added; sterility control: RPMI medium only, with no organisms or drug added). The MABA was used according the manufacturer's instructions (Invitrogen), adding $20 \mu \mathrm{L}$ to the well of Alamar Blue at $72 \mathrm{~h}$ and the plates were incubated for an additional $24 \mathrm{~h}$, totalling 4 days for the MIC final reading. The lowest antifungal agent concentration that substantially inhibited the growth of the organism was visually determined at the point at which there was no change in the original blue colour of the reagent. The fungal growing in each well was also monitored using an inverted microscopy.

\subsection{Animals and experimental infection}

Male Balb/c mice, 5-7 weeks old at the time of inoculation were obtained from the Central Bioterium of University of Campinas (UNICAMP, Brazil). For each independent experiment, 5 mice by groups were were used. Animals were intraperitoneally inoculated with $100 \mu \mathrm{L}$ with $10^{7} \mathrm{~S}$. schenckii yeast cells in PBS or with an equal volume of PBS alone. $24 \mathrm{~h}$ after fungal inoculation the animals were treated with test substances (extract or antifungal). The groups and their dosages were as follows: VGB - Infected animals that received a daily dose of $10 \mathrm{mg} / \mathrm{kg}$ body weight of the stem bark extract of $V$. guianensis. VGL - Infected animals that received a daily dose of $10 \mathrm{mg} / \mathrm{kg}$ body weight of the extract of the leaves of $V$. guianensis, ITR - Infected animals that received a daily dose of $10 \mathrm{mg} / \mathrm{kg}$ weight of itraconazole. Infected - Infected animals receiving a daily dose of saline, serving as a placebo. Uninfected - Animals uninfected and untreated. All the treatment were administered by oral gavage. The dose of $10 \mathrm{mg} / \mathrm{kg}$ was chosen in this study taking into count that this is an effective therapeutic dose of ITR by oral way in human and feline sporotrichosis (Batista-Duharte et al., 2015; de Souza et al., 2016). Thus, we use this dose as reference to compare the potency in vivo of the plant extracts.

All procedures with laboratory animals were approved by the Institutional Ethics Committee and were in accordance with National Institutes of Health Animal Care Guidelines (Protocol N $N^{\circ}$ 06/2014 CEUA/FCF/Car).

\subsection{Obtaining peritoneal exudate cells}

The animals were previously stimulated by intraperitoneal (i.p) inoculation of $3.0 \mathrm{~mL}$ of $3.0 \%$ sodium thioglycollate, three days before the collection of cells. After this period, the animals were euthanized by $\mathrm{CO}_{2}$ inhalation chamber. These animals had their abdominal skin removed aseptically in a laminar flow chamber and exposed peritoneum. In the upper middle portion of the abdomen were injected $5.0 \mathrm{~mL}$ of phosphate buffered saline (PBS) at $\mathrm{pH} 7.2$ and $4{ }^{\circ} \mathrm{C}$ with the aid of well sterile syringe and needle. A light hand massage was performed and peritoneal exudate cells were collected with the same syringe and dispensed in sterile conical tube for preparation of the cell suspension. The peritoneal exudate cells were washed three times with $5 \mathrm{~mL}$ of PBS (pH 7.2) and centrifuged at $400 \times g$ for $5 \mathrm{~min}$ in a centrifuge at room temperature. The pelleted cells were re-suspended in $1.0 \mathrm{~mL}$ of RPMI-1640 culture medium containing $2 \beta 2 \times 10-5 \mathrm{M}$ mercaptoethanol, penicillin $100 \mathrm{U} / \mathrm{mL}$ streptomycin, $100 \mathrm{U} / \mathrm{mL}$, $2 \mathrm{mM}$ L-glutamine and 5\% serum fetal bovine, and the medium compound so designated RPMI-1640 complete medium (RPMI-1640C). The number of cells was determined by counting in a Neubauer chamber hemocitométrica using $10 \mu \mathrm{L}$ of the diluted cell suspension in $90 \mu \mathrm{L}$ of liquid Lazarus. Cells were adjusted to the optimum concentration for each test in RPMI-1640-C.

\subsection{Spleen removal and systemic fungal load study}

Spleen from each mouse was aseptically removed and passed through a $100 \mu \mathrm{m}$ cell strainer with the aid of a syringe plunger into a Petri dish containing $2 \mathrm{~mL}$ of PBS. The assessment of the systemic fungal load was performed by counting the CFU grown on Mycosel agar plates after the inoculation of a previously determined dilution of the spleen macerate, collected before the red cell lyses treatment.

\subsection{Preparation of total splenocytes}

Splenocytes were obtained as described above. For red cell lyses, the resulting suspension was added with $6 \mathrm{~mL}$ of a $0.17 \mathrm{M}$ ammonium chloride solution and then incubated in ice for $5 \mathrm{~min}$. Splenocytes were separated from the supernatant by centrifugation at $300 \times g$ for $5 \mathrm{~min}$ at $4{ }^{\circ} \mathrm{C}$, washed once with $3 \mathrm{~mL}$ of RPMI complete medium and then 

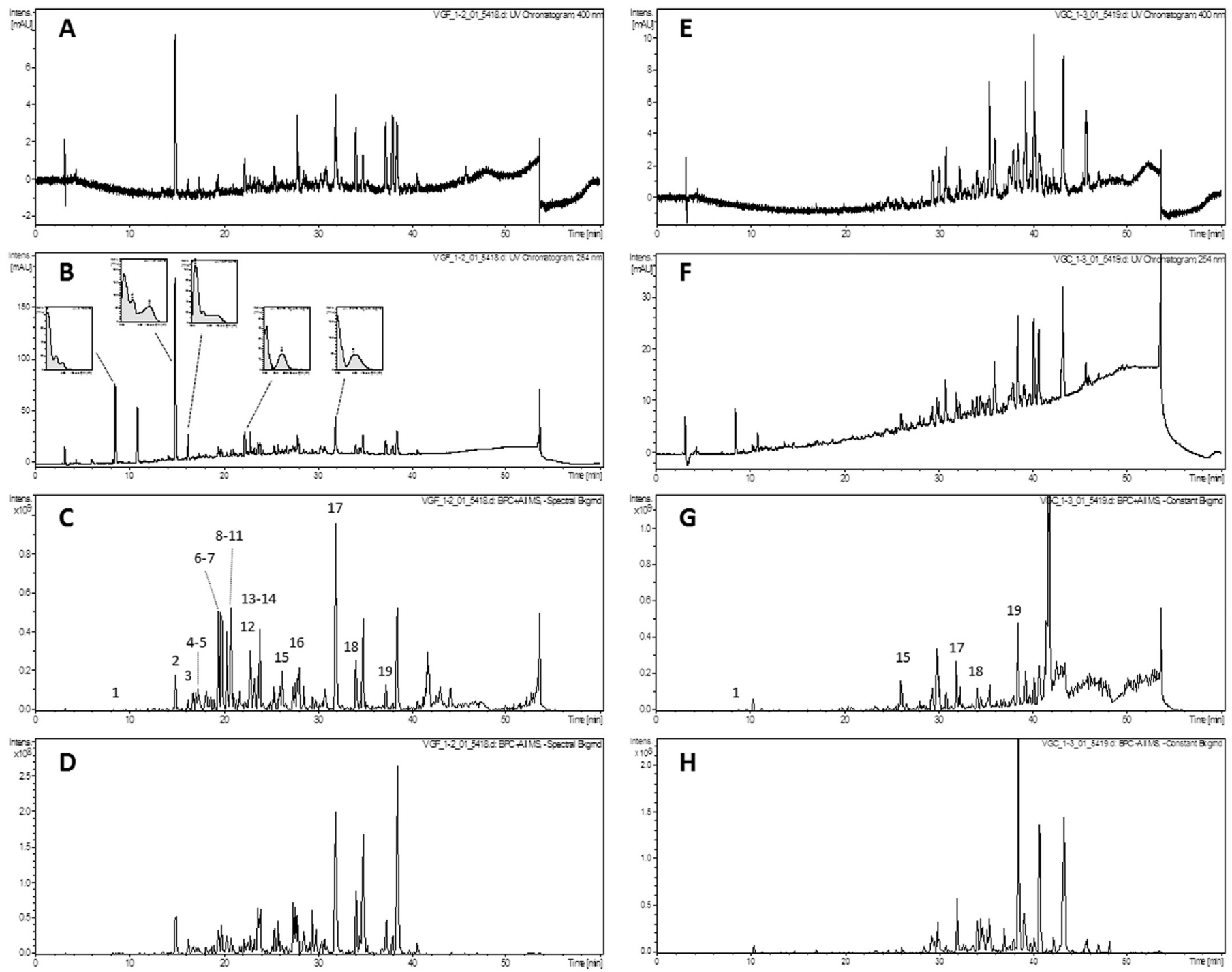

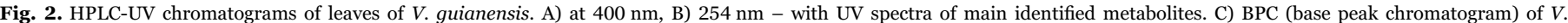

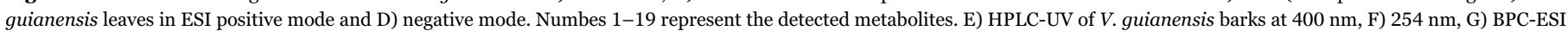
positive and $\mathrm{H}$ ) negative modes.

resuspended in $1 \mathrm{~mL}$ of the same medium. Cell concentration was determined by microscopy using the Trypan blue exclusion test and then adjusted to $5 \times 10^{6}$ cells $/ \mathrm{mL}$ in RPMI complete medium.

\subsection{Evaluation of cellular viability}

The bromide 3- (4,5-dimethylthiazol-2)-2,5-diphenyltetrazolium bromide (MTT) colorimetric assay was used for the determination of cell viability of PEC. This assay is based on checking the activity and mitochondrial integrity interpreted as a measure of cell viability. The cell suspension were adjusted to a concentration of $5 \times 10^{6}$ cells $/ \mathrm{mL}$. $100 \mu \mathrm{L}$ of the suspension was added to 96 -well plates. The plates were incubated for $1 \mathrm{~h}$ with three concentrations $(25,50$ or $100 \mu \mathrm{g} / \mathrm{mL})$ of either VGL or VGB extracts at $37^{\circ} \mathrm{C}$ and $5 \% \mathrm{CO}_{2}$. Only cells and culture medium RPMI-1640-C were used as a control, equivalent to $100 \%$ viability of macrophages. Measurements were taken using a spectrophotometer UV/Visible microplate at $540 \mathrm{~nm}$ with reference filter at $620 \mathrm{~nm}$ (Mosmann, 1983). Before the determination of nitric oxide and cytokine production by macrophages and lymphocytes from infected and non-infected mice the cell viability was also measured (Supplementary material).

\subsection{Determination of nitric oxide production}

Nitric oxide was quantitated by accumulation of nitrite in the culture medium is measured spectrophotometrically using the Griess reagent with $\mathrm{NaNO}_{2}$ as standard (Green et al., 1982). The obtained cell suspension was adjusted to $5 \times 10^{6}$ cells/mL in RPMI-1640 medium. $100 \mu \mathrm{L}$ were distributed this cell suspension in sterile 96 well plate. After this period, the supernatant was discarded. In some wells plate, $100 \mu \mathrm{L}$ of the extracts were added at a concentration of $50 \mu \mathrm{g} / \mathrm{mL}$. In others wells, $100 \mu \mathrm{L}$ of LPS solution containing $10 \mu \mathrm{g} / \mathrm{mL}$ as a stimulant agent (positive control), and still other wells were added $100 \mu \mathrm{L}$ of RPMI-1640 medium to the cell suspension as control cells (negative control). The plate was incubated for $24 \mathrm{~h}$ at $37^{\circ} \mathrm{C}$ with $\mathrm{CO}_{2}$ (5\%). After incubation, $50 \mu \mathrm{L}$ aliquots of each sample were withdrawn and passed to the plate and another additional $50 \mu \mathrm{L} /$ well Griess reagent, consisting of $0.1 \% \mathrm{~N}$-1-naphthyl-ethylenediamine, $0,1 \%$ sulfanilamide solution of $3 \%$ phosphoric acid. After $10 \mathrm{~min}$ in the dark at room temperature, the plates were read in a spectrophotometer UV/ Visible microplate with $540 \mathrm{~nm}$ filter. Sodium nitrite concentrations were calculated from a standard curve previously established with known molar concentrations of sodium nitrite in RPMI-1640 medium. The tests were performed in triplicate and the values expressed in 
Table 1

Metabolites detected by HPLC-DAD-IT MS/MS (ESI positive and negative modes) of $V$. guianensis extracts.

\begin{tabular}{|c|c|c|c|c|c|c|c|c|}
\hline $\mathrm{n}^{\circ}$ & Rt (min) & $\begin{array}{l}\text { UV max } \\
(\mathbf{n m})\end{array}$ & Identification* & {$[\mathbf{M}-\mathbf{H}]^{-}$} & Fragmentation & {$[\mathbf{M}+\mathbf{H}]^{+}$} & Fragmentation & Ref \\
\hline 1 & 8.2 & 330 & chlorogenic acid & 353.2 & $\mathrm{MS}_{2}[353] 191 ; 179 ; 135$ & - & - & - \\
\hline 2 & 14.8 & 348,255 & quercetin-O-deoxyhexose & 447.2 & $\begin{array}{l}\mathrm{MS}_{2}[447] 301 ; 269 ; 257 ; 229 ; \\
191 ; 179 ; 151\end{array}$ & 449.2 & $\mathrm{MS}_{2}[449] 303 ; 257 ; 219 ; 129$ & $\begin{array}{l}\text { Vikic and } \\
\text { Guttman, } 2010\end{array}$ \\
\hline 3 & 16.2 & 345,265 & kaempferol-O-deoxyhexose & 431.1 & $\mathrm{MS}_{2}[431] 285 ; 255 ; 179 ; 163$ & 433.1 & $\begin{array}{l}\mathrm{MS}_{2}[433] 287 ; 259 ; 219 ; 153 ; 147 ; \\
129\end{array}$ & $\begin{array}{l}\text { Vikic and } \\
\text { Guttman, } 2010\end{array}$ \\
\hline 4 & 17.4 & 287,370 & $\begin{array}{l}\text { hydroxyl-vismiaguianone D or } \\
\text { E }\end{array}$ & 443.2 & $\begin{array}{l}\mathrm{MS}_{2}[443] 425 ; 413 ; 385 ; 367 ; \\
343 ; 331 ; 313 ; 299 ; 291 ; 271 ; \\
255 ; 187 ; 161\end{array}$ & 445.2 & $\mathrm{MS}_{2}[445] 427 ; 409 ; 387 ; 373 ; 355$ & Seo et al., 2000 \\
\hline 5 & 17.5 & 288 & benzophenone derivative & 413.2 & $\begin{array}{l}\mathrm{MS}_{2}[413] 395 ; 355 ; 341 ; 319 ; 293 ; \\
283 ; 269 ; 225 ; 177 ; 137\end{array}$ & 415.2 & $\begin{array}{l}\mathrm{MS}_{2}[415] 397 ; 379 ; 343 ; 325 ; 303 \\
267 ; 249 ; 175 ; 133\end{array}$ & $\begin{array}{l}\text { Fuller et al., } \\
1999\end{array}$ \\
\hline 6 & 19.4 & 287,370 & $\begin{array}{l}\text { hydroxyl-vismiaguianone D or } \\
\text { E }\end{array}$ & 443.2 & $\begin{array}{l}\mathrm{MS}_{2}[443] 425 ; 411 ; 393 ; 385 ; \\
349 ; 323 ; 317 ; 299 ; 287 ; 247 \\
165 ; 137\end{array}$ & 445.2 & $\begin{array}{l}\mathrm{MS}_{2}[445] 427 ; 413 ; 373 ; 355 ; 341 \\
297 ; 267 ; 185\end{array}$ & Seo et al., 2000 \\
\hline 7 & 19.9 & 284 & vismiaguianone derivative & 457.2 & $\begin{array}{l}\mathrm{MS}_{2}[457] 425 ; 401 ; 367 ; 331 ; 303 ; \\
255 ; 229 ; 201 ; 185 ; 163 ; 147\end{array}$ & 459.3 & $\begin{array}{l}\mathrm{MS}_{2}[459] 427 ; 409 ; 387 ; 355 ; 247 ; \\
237\end{array}$ & Seo et al., 2000 \\
\hline 8 & 20.4 & 289 & vismiaguianone $\mathrm{D}$ or $\mathrm{E}$ & 427.2 & $\begin{array}{l}\mathrm{MS}_{2}[427] 412 ; 395 ; 383 ; 369 ; 333 ; \\
307 ; 275 ; 257 ; 243 ; 137\end{array}$ & 429.2 & $\begin{array}{l}\mathrm{MS}_{2}[429] 411 ; 357 ; 339 ; 309 ; 281 ; \\
263\end{array}$ & Seo et al., 2000 \\
\hline 9 & 22.7 & 263,310 & vismiaguianone derivative & 445.3 & $\begin{array}{l}\mathrm{MS}_{2}[445] 427 ; 413 ; 375 ; 351 ; \\
319 ; 293 ; 275 ; 251 ; 237 ; 205 \\
161 ; 137\end{array}$ & 447.2 & $\begin{array}{l}\mathrm{MS}_{2}[447] 429 ; 411 ; 393 ; 375 ; 357 ; \\
339 ; 303 ; 259 ; 227 ; 203 ;\end{array}$ & Seo et al., 2000 \\
\hline 10 & 22.7 & 292 & benzophenone derivative & 413.2 & $\begin{array}{l}\mathrm{MS}_{2}[413] 395 ; 383 ; 369 ; 355 ; 339 ; \\
355 ; 325 ; 319 ; 293 ; 283 ; 231 ; \\
223 ; 141\end{array}$ & 415.2 & $\begin{array}{l}\mathrm{MS}_{2}[415] 397 ; 379 ; 343 ; 321 ; 303 \\
267 ; 249 ; 215 ; 121\end{array}$ & $\begin{array}{l}\text { Fuller et al., } \\
1999\end{array}$ \\
\hline 11 & 22.9 & 293 & benzophenone derivative & 367.1 & $\begin{array}{l}\mathrm{MS}_{2}[367] 353 ; 336 ; 318 ; 309 ; 291 ; \\
265 ; 252 ; 247 ; 216\end{array}$ & 369.1 & $\begin{array}{l}\mathrm{MS}_{2}[369] 351 ; 297 ; 275 ; 259 ; 231 ; \\
203 ; 121\end{array}$ & $\begin{array}{l}\text { Fuller et al., } \\
1999\end{array}$ \\
\hline 12 & 23.6 & $\begin{array}{l}285,337 \\
(\mathrm{sh})\end{array}$ & vismiaguianone $\mathrm{D}$ or $\mathrm{E}$ & 427.2 & $\begin{array}{l}\mathrm{MS}_{2}[427] 395 ; 377 ; 357 ; 333 \\
325 ; 313 ; 307 ; 237 ; 137\end{array}$ & 429.2 & $\mathrm{MS}_{2}[429] 411 ; 393 ; 339 ; 264$ & Seo et al., 2000 \\
\hline 13 & 25.8 & $\begin{array}{l}289,335 \\
(\mathrm{sh})\end{array}$ & sesamin & 353.1 & $\begin{array}{l}\mathrm{MS}_{2}[353] 336 ; 323 ; 293 ; 281 ; \\
259 ; 133\end{array}$ & 355.2 & $\begin{array}{l}\mathrm{MS}_{2}[355] 337 ; 331 ; 293 ; 279 ; 261 ; \\
231 ;\end{array}$ & Yan et al., 2007 \\
\hline 14 & 25.8 & $\begin{array}{l}289,335 \\
(\mathrm{sh})\end{array}$ & unknown & 371.2 & $\begin{array}{l}\mathrm{MS}_{2}[371] 339 ; 321 ; 277 ; 245 ; \\
233 ; 205\end{array}$ & 373.2 & $\begin{array}{l}\mathrm{MS}_{2}[373] 355 ; 313 ; 301 ; 279 ; 261 ; \\
195\end{array}$ & - \\
\hline 15 & 27.5 & $\begin{array}{l}285,337 \\
(\mathrm{sh})\end{array}$ & vismiaguianone derivative & 427.2 & $\begin{array}{l}\mathrm{MS}_{2}[427] 409 ; 395 ; 357 ; 341 ; \\
333 ; 301 ; 263 ; 247 ; 231 ; 207 ; \\
187 ; 161 ; 149\end{array}$ & 429.2 & $\begin{array}{l}\mathrm{MS}_{2}[429] 411 ; 393 ; 357 ; 339 ; 313 ; \\
299 ; 275 ; 263 ; 255 ; 225 ; 219 ; 189 ; \\
121\end{array}$ & Seo et al., 2000 \\
\hline 16 & 28.5 & 289 & vismiaphenonederivative & 397.2 & $\begin{array}{l}\mathrm{MS}_{2}[397] 379 ; 339 ; 325 ; 303 ; \\
231 ; 163 ; 149\end{array}$ & 399.2 & $\begin{array}{l}\mathrm{MS}_{2}[399] 381 ; 343 ; 327 ; 305 ; 267 ; \\
233 ; 205 ; 199\end{array}$ & $\begin{array}{l}\text { Fuller et al., } \\
1999\end{array}$ \\
\hline 17 & 31.9 & 310 & vismiaphenone $\mathrm{G}$ & 411.2 & $\begin{array}{l}\mathrm{MS}_{2}[411] 379 ; 367 ; 327 ; 319 ; \\
291 ; 259 ; 221\end{array}$ & 413.2 & $\begin{array}{l}\mathrm{MS}_{2}[413] 395 ; 357 ; 341 ; 319 ; 302 ; \\
263 ; 247 ; 191 \\
\mathrm{MS}_{2}[357] 339 ; 281 ; 263 ; 245 \\
221 ; 193 ; 169 ; 119\end{array}$ & $\begin{array}{l}\text { Fuller et al., } \\
1999\end{array}$ \\
\hline 18 & 34.5 & 290 & unknown & 355.2 & $\begin{array}{l}\mathrm{MS}_{2}[355] 341 ; 301 ; 261 ; 249 ; \\
235 ; 233 ; 219\end{array}$ & 357.2 & $\begin{array}{l}\mathrm{MS}_{2}[357] 339 ; 325 ; 301 ; 263 ; 207 ; \\
191 ; 175\end{array}$ & - \\
\hline 19 & 36.9 & 298 & vismiaphenone D & 395.3 & $\begin{array}{l}\mathrm{MS}_{2}[395] 380 ; 337 ; 325 ; 301 ; \\
275 ; 257 ; 233\end{array}$ & 397.2 & $\begin{array}{l}\mathrm{MS}_{2}[397] 379 ; 341 ; 325 ; 285 ; 231 ; \\
203 ; 121\end{array}$ & $\begin{array}{l}\text { Fuller et al., } \\
1999\end{array}$ \\
\hline
\end{tabular}

Table 2

In vitro direct antifungal activity of VGL, VGB AND ITR after $48 \mathrm{~h}$.

\begin{tabular}{llll}
\hline Evaluated substances & MICs & $\begin{array}{l}\text { MABA }(\boldsymbol{\mu g} / \\
\mathbf{m L})\end{array}$ & $\begin{array}{l}\text { MIC range }(\boldsymbol{\mu g} / \mathbf{m L}) \\
\mathbf{I T R}^{\mathbf{a}}\end{array}$ \\
\hline VGL & 3.9 & 3.9 & - \\
VGB & 3.9 & 3.9 & - \\
ITR & 0.97 & 0.97 & $0.25-1.0$ \\
\hline
\end{tabular}

MIC: minimum inhibitory concentration

MABA: microplate AlamarBlue assay.

a Itraconazole( ITR) MIC range determined in 19 S. schenckii strains (AlvaradoRamírez and Torres-Rodríguez 2007).

$\mu$ mols NO $/ 5 \times 10^{6}$ cells.

2.13. Determination of the inhibitory activity of $V$. guianensis extracts in peritoneal cell cultures of mice for the production of NO

Peritoneal exudate cells were used at a concentration of $5 \times 10^{6}$ cells $/ \mathrm{mL}$. Cells were incubated in the concomitant presence of $100 \mu \mathrm{L}$ of LPS solution $(10 \mathrm{mg} / \mathrm{mL})$ and $100 \mathrm{~mL}$ of extracts at a concentration of $100 \mu \mathrm{g} / \mathrm{mL}$. Incubation was performed for $24 \mathrm{~h}$ at $37^{\circ} \mathrm{C}$ with $\mathrm{CO}_{2}$ (5\%). NO production was measured spectrophotometrically at nitrite accumulation in the culture medium using the Griess reagent in the same way as in NO production test.

\subsection{Determination of $T N F-\alpha, I F N-\gamma, I L-4, I L-10$ and $I L-12$}

The cytokines TNF- $\alpha$ and IL-12, were quantified in the supernatant obtained from the culture of macrophages, while IL-4, IL-10 and IFN- $\gamma$ in splenocytes culture, using ELISA immunoenzymatic assay, (Pharmingen) according to the instructions manufacturer. Polystyrene 96 well microplates were adsorbed with a capture antibody (mouse serum) anti-IL-4, anti-IL-10, anti-IL-12, anti-TNF- $\alpha$ purified mouse or the $4 \mu \mathrm{g} / \mathrm{mL}(100 \mu \mathrm{L} /$ well) and incubated in PBS buffer "overnight" at room temperature. The plates were washed 3 times with phosphate buffered saline, pH 7.2 (PBS) containing 0.05\% Tween-20 (PBS-T). After washing, $300 \mu \mathrm{L}$ were blocked with $1 \%$ BSA in PBS (PBS / BSA, $5 \%$ sucrose and $0.5 \%$ sodium azide) at room temperature for $60 \mathrm{~min}$ and washed 3 times with PBS-T. It was added to the plate $100 \mu \mathrm{L}$ of each pattern of cytokine or cell culture supernatants. The plates were incubated at room temperature for $120 \mathrm{~min}$, and washed 4 times with PBS-T. Then was added $100 \mu \mathrm{L} /$ well of monoclonal antibody goat anti-IL-4, anti-IL-10, anti-IL-12, anti-mouse TNF- $\alpha$ labeled with biotin at a concentration of $400 \mathrm{ng} / \mathrm{mL}$ reagent diluent (1\% BSA, $0.05 \%$ Tween 20 in Tris- $\mathrm{NaCl}$ buffer). The plates were incubated at 


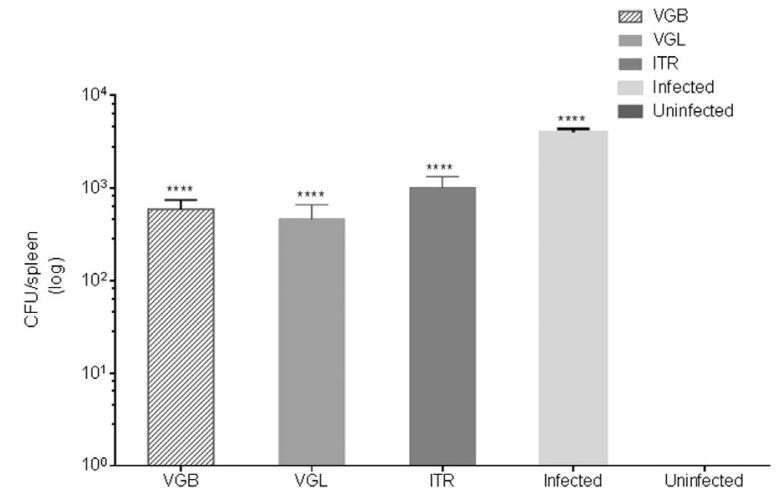

Fig. 3. Fungal loads in the spleen of a Balb/c model of infection with $S$. schenckii ATCC 16345. The mice were organized into 5 groups one of which was not infected with $S$. schenckii. Infected animals were inoculated i.p with $10^{6}$ yeast $S$. schenckii. These were divided into 4 groups: VGC (infected and treated animals with the stem bark extract of $V$. guianensis); VGF (infected and treated animals with the extract of V. guianensis leaves); ITR (animals infected and treated with itraconazole) and only infected and untreated animals. Statistical significance was determined by 2-way ANOVA for multiple comparisons using the Sidak test and confidence interval ${ }^{*}(\mathrm{p}<0.05),{ }^{* *}(\mathrm{p}<0.01),{ }^{* * *}(\mathrm{p}<0.001)$ and $* * *(\mathrm{p}<0.0001)$ compared with the control group at each point corresponding unless otherwise indicated. Results are presented as mean \pm standard deviation of 3 animals.

room temperature for 120 min and washed 3 times with PBS-T, and then added $100 \mu \mathrm{L}$ streptavidin-peroxidase conjugate diluted in PBS/ BSA and further incubated at room temperature for $30 \mathrm{~min}$. After this process, the plates were washed 3 times with PBS-T and $100 \mu \mathrm{L}$ of substrate $(10 \mathrm{mM}$ citrate-phosphate buffer containing $0.4 \mathrm{mM}$ tetramethylbenzidine [Sigma] and $1.2 \mathrm{mM} \mathrm{H}_{2} \mathrm{O}_{2}$ ) were added to each well. The reaction was stopped by adding $50 \mu \mathrm{L}$ of $2 \mathrm{~N} \mathrm{H}_{2} \mathrm{SO}_{4}$. The absorbance was read at $450 \mathrm{~nm}$ in a spectrophotometer UV/vis microplate and cytokine concentrations were quantified using a previously established standard curve with known amounts of IL-4, IL-10, IL-12, IFN- $\gamma$ or TNF- $\alpha$, standard. The tests were performed in triplicate and the results expressed as $\mathrm{pg} / \mathrm{mL}$.

\subsection{Statistical analysis}

The data obtained were analysed by the Prism program Version 4.0 (GraphPad Software, Inc., La Jolla, CA, USA) and expressed as the means $\pm \mathrm{SD}$ of each experimental group. To determine statistically significant differences between groups an ANOVA for multiple comparisons using the Sidak test and confidence interval ${ }^{*}(p<0.05),{ }^{* *}(p$ $<0.01),{ }^{* * *}(\mathrm{p}<0.001)$ and ${ }^{* * * *}(\mathrm{p}<0.0001)$.

\section{Results and discussion}

According to World Health Organization, medicinal plants would be the best source of a variety of drug. Unfortunately, traditional medicines based on plant products remains empirical regarding, doses, durations of treatment or interactions with other drugs are not clearly defined. Therefore there are urgent necessities for chemical and pharmacological studies that may help achieve the standardization of such treatment (Uma et al., 2016).

Sporotrichosis is an opportunistic infection where the immunocompetence is determinant in the pathogenesis (Gutierrez-Gallardo et al., 2015). Studies developed in our lab evidenced that different immune mechanisms of the innate and adaptative immune response, are involved in the defence against $S$. schenckii (Gonçalves et al., 2015; Ferreira et al., 2015; Maia et al., 2016; Negrini et al., 2013; Sassá et al., 2012; Portuondo et al., 2016). On the other hand, it was observed that an excessive inflammatory reaction induced by the infection could be deleterious, causing tissular damages and even hindering the efficient fungal elimination (Maia et al., 2016). In this way, it was described that the exogenous supply of antioxidants, as natural compounds that scavenge free radicals, might represent an important additional tool for the treatment of opportunistic fungal infections during HIV infection (Otang et al., 2012). These findings suggest that the strategy associating immunomodulator/antinflammatory compounds with antifungal drugs seems to be promissory to improve the treatment efficacy in infections by $S$. schenckii (Guterres et al., 2014; Batista-Duharte et al., 2015, 2016).

Several etnomedical and experimental studies showed that plants of the Vismia genus, have significant antifungal effect against Candida sp. and C. neoformans (Kuete et al., 2007; Tamokou et al., 2009; Vizcaya et al., 2012) but so far there is not studies of the antifungal effect of this genus against $S$. schenckii. In the present study, the anti-inflammatory activity of $V$. guianensis extracts and antifungal activity against $S$. schenckii were investigated for the first time.

Firstly, a phytochemical screening was performed in order to identify the main classes of compounds present in the species $V$. guianensis. The results evidenced the presence of polyphenol compounds as anthraquinones, flavonoids and tanines. Furthermore, in situ identification based on LC-DAD-IT MS/MS were performed by onflow data-dependent acquisition mode (autoMSMS) in alternated positive and negative electrospray ionization modes for comprehensive data collection with the measurement of CID fragment spectra from all detectable metabolites of the sample after isolation of the corresponding parent ions by the trap (Broecker et al., 2011).

After data acquisition, the MS/MS spectra were cross referenced against database (DPN, Metlin, Massbank) considering all data reported in the literature for Vismia taxon (Hussain et al., 2012; Carnevale-Neto et al., 2013). The putative molecular detections were justified based on measured $m / z$, UVmax and MS/MS fragmentation. The integrated LC-DAD-MSMS approach, depicted in Fig. 2, led to the detection of 19 known metabolites (Table 1), classified in flavonoids $O$ glycosides and prenylated benzoquinone as vismiaphenone and vismiaguianone derivatives previously described for Vismia (Fuller et al., 1999; Seo et al., 2000; Hussain et al., 2012).

Flavonoids are phenolic compounds found in much higher plants and are characterized by their antioxidant action (Vukics and Guttman, 2010; Carnevale-Neto et al., 2013). Polyisoprenylated benzophenones were mainly present in the fruits, twigs, pericarps, stems, leaves, stem bark, fruit hulls and pulp of the genus Vismia and important chemomarkers in Clusiaceae. These molecules are known for antifungal activity, usually related to pyran moiety (Rubio et al., 1999; Kumar et al., 2013). Wabo and colleagues 2007 demonstrated moderate activity of xanthones, isolated from $V$. laurentii against Gram-positive (Wabo et al., 2007). In another study, Suffredini and coworkers 2006 determined that the extracts of $V$. guianensis have not significant antimicrobial activity against the bacteria $E$. coli, P. aeruginosa, $S$. aureus and E. faecalis, since the MIC was greater than $200 \mu \mathrm{g} / \mathrm{mL}$ (Suffredini et al., 2006). However, in this study a potent antifungal activity for both leaves and bark was evidenced, even in comparison with the reference drug ITR. In the microdilution assays, extract concentrations ranged from 500 to $0.000875 \mu \mathrm{g} / \mathrm{mL}$ for the plant extracts and 16 to $0.00003 \mu \mathrm{g} / \mathrm{mL}$ for ITR. It was observed that the Minimum Inhibitory Concentration (MIC) of the VGL and VGB extract were $3.9 \mu \mathrm{g} / \mathrm{mL}$, while itraconazole $(0.0078<16 \mu \mathrm{g} / \mathrm{mL})$ was able to inhibit fungal growth until $0.97 \mu \mathrm{g} / \mathrm{mL}$ tested at $48 \mathrm{~h}$ of incubation (Table 2).

The antifungal in vitro study matched with the in vivo study where a significant reduction of the fungal load in the spleen, as reference target organ, after treatment with both extracts was observed. Surprisingly in this study it was detected that after 7 days of treatment in the infected animals group, VGL extract reduced the fungal infection in $53.9 \%\left(1.6 \times 10^{4} \mathrm{CFU}\right)$, whereas ITR, reduced infection over $46.4 \%$ $\left(1.9 \times 10^{4} \mathrm{CFU}\right)$ compared to untreated animals $\left(3.6 \times 10^{4} \mathrm{CFU}\right)$ (Fig. 3). Although more studies are necessary to elucidate the mechanisms of this effect, we think that the immunomodulator effects of the plant can 

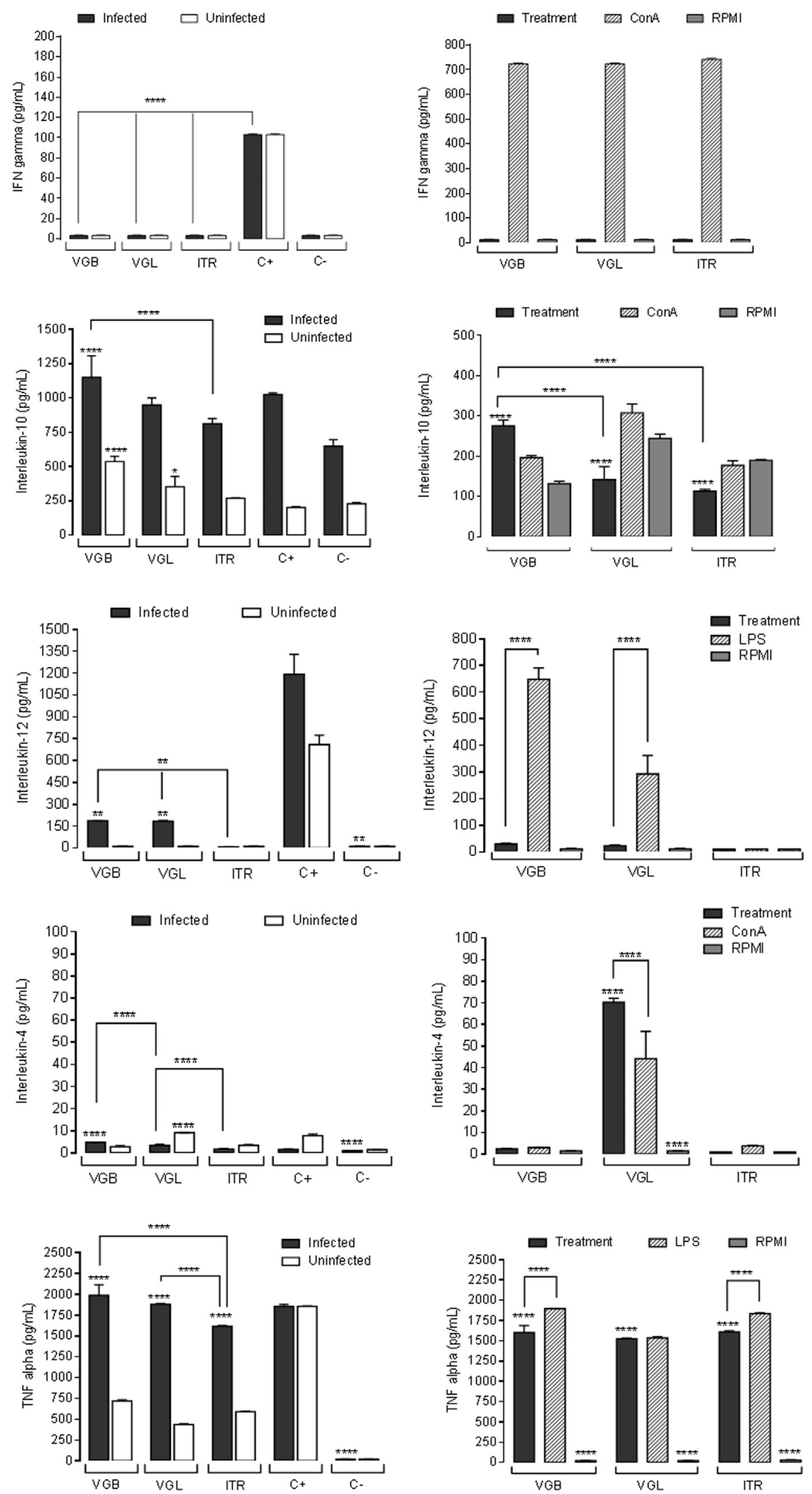

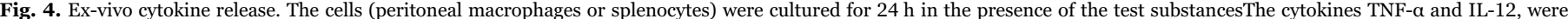

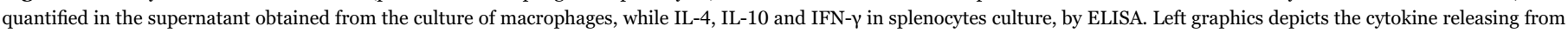

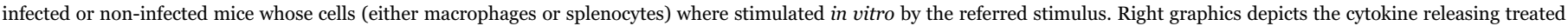

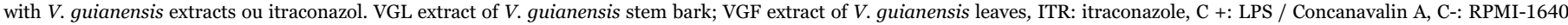

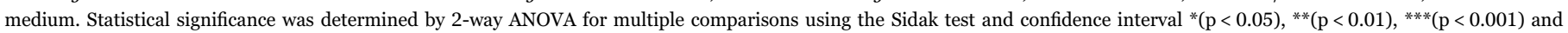
$* * * *(p<0.0001)$ compared with the control group at each point corresponding unless otherwise indicated. Results are presented as mean \pm standard deviation of 3 animals. 

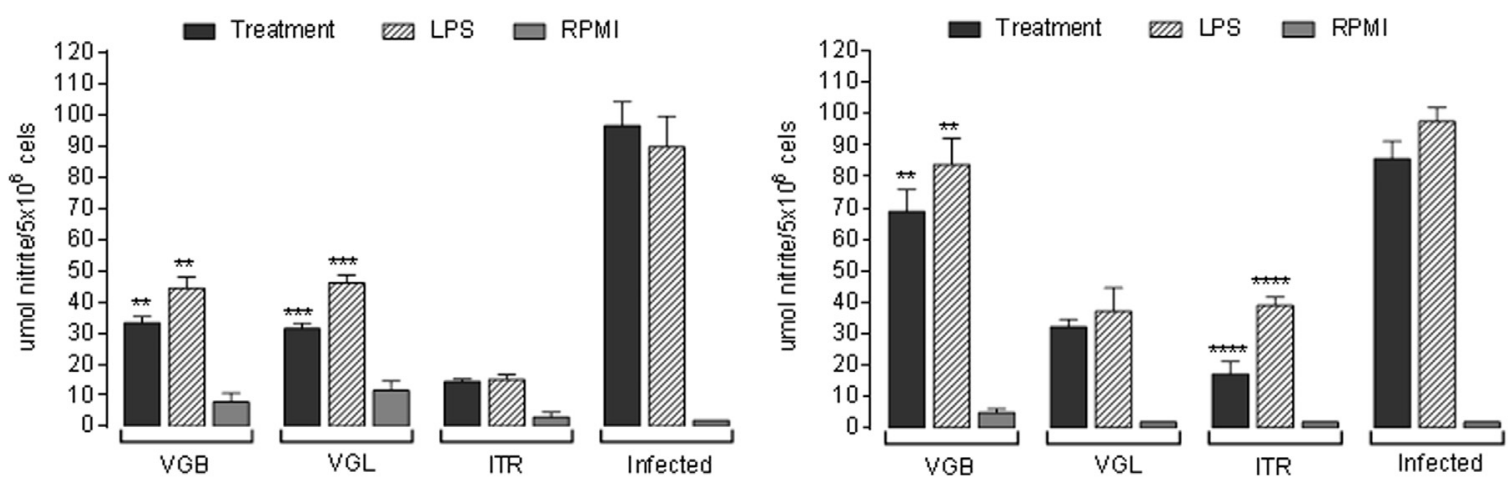

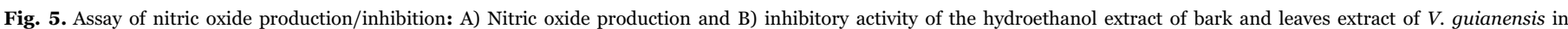

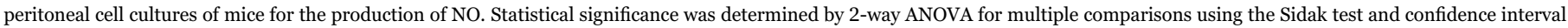
${ }^{* *}(\mathrm{p}<0.01)$, and ${ }^{* * * *}(\mathrm{p}<0.0001)$ compared with the control group.

be involved in the more effective fungal clearance in comparison with ITR. A recent study suggested that an early immune response could be sufficient to overcome the fungal infection without antifungal drugs in this model (Ferreira et al., 2015).

The ex vivo cytokine release demonstrated that animals treated with extract from either leaves and barks are able of induce the production of cytokines, such as IL-10 and TNF-alpha and in lower proportion IL-4, IL-12, mainly in infected mice, while IFN- $\gamma$, other important cytokine participating in the immune response, is not stimulated (Fig. 4). These results suggest that the stimulation observed in the infected animals were consequence of the fungal infection, and the treatment can favours a profile anti-inflammatory. This pattern with reduction of pro-inflammatory cytokines and elevated production of IL-10 is associated with anti-inflammatory effect in plants (Wang et al., 2016). In addition, the observed result regarding the reduction of NO production, associated to the treatment with the extracts also support our hypothesis about the anti-inflammatory activity of the plant (Fig. 5).

The inflammatory response triggered by certain infections is frequently the cause of tissue damage and death (Garcia et al., 2010). In this way, this favourable anti-inflammatory profile induced by the evaluated extracts can be potentially important for reducing the tissular damage associated to the infectious process, helping for a faster recovery.

This study is the first to show the antifungal effect of $V$. guianensis against $S$. schenckii in vitro and in vivo as well as an antinflammatory effect that can act synergically to reduce the deleterious effect of the fungal infection and a faster relieve. These pharmacological effects observed seem to be associated to the balanced compositions of the extracts. Under this point of view, $V$. guianensis might be investigated as a promising candidate for antifungal treatment against sporotrichosis, specially with in situ detection of several prenylated benzoquinone with known antifungal effect. Further studies are being conducted to elucidate the antifungal and immunomodulatory mechanism of action of these extracts and the role of each component in the described effects.

\section{Conflicts of interest}

The authors declare no commercial or financial conflict of interest.

\section{Acknowledgement}

This work was supported by Bioscience and Biotechnology Applied to Pharmacy Pos-graduate Program from Pharmaceutical Sciences Faculty, UNESP, Araraquara, SP, Brazil, and Conselho Nacional de Desenvolvimento Científico e Tecnológico (CNPq).

\section{Appendix A. Supporting information}

Supplementary data associated with this article can be found in the online version at doi:10.1016/j.jep.2016.11.030.

\section{References}

Almeida-Cortez, J.S., Melo-de-Pinna, G.F., 2006. Morphology and anatomy of a leaf mine in Vismia guianensis (Aubl.) Choisy (Clusiaceae) in a fragment of Brazilian Atlantic forest. Braz. J. Biol. 66 (2B), 759-763.

Apisariyakul, A., Vanittanakom, N., Buddhasukh, D., 1995. Antifungal activity of turmeric oil extracted from Curcuma longa (Zingiberaceae). J. Ethnopharmacol. 49, $163-169$.

Batista-Duharte, A., Pereira, AS., Freitas, DFS., Portuondo, DF., Gutierrez-Galhardo, MC, Carlos, IZ. Therapeutic and prophylactic tools for sporotrichosis: Current strategies and future tendencies. In: Carlos IZ ed. Sporotrichosis. New developments and future prospects. ISBN 978-3-319-11911-3. Springer International Publishing Switzerland. 2015 pp 147-177

Batista-Duharte, A., Lastre, M., Romeu, B., Portuondo, D.L., Téllez-Martínez, D., Manente, F.A., Pérez, O., Carlos, I.Z., 2016. Antifungal and immunomodulatory activity of a novel cochleate for amphotericin B delivery against Sporothrix schenckii. Int Immunopharmacol. 40, 277-287.

Broecker, S., Herre, S., Wust, B., Zweigenbaum, J., Pragst, F., 2011. Development and practical application of a library of CID accurate mass spectra of more than 2,500 toxic compounds for systematic toxicological analysis by LC-QTOF-MS with datadependent. Anal. Bioanal. Chem. 400, 101-117.

Carlos, I.Z, Batista-Duharte, A. Sporotrichosis: An emergent disease In: Carlos IZ ed. Sporotrichosis. New developments and future prospects. ISBN ISBN 978-3-31911911- 3. Springer International Publishing Switzerland. 2015 pp 1-23

Carnevale-Neto, F., Siquitelli, C.D., Pilon, A.C., Silva, D.H.S., Bolzani, V.S., CastroGamboa, I., 2013. Dereplication of phenolic derivatives of Qualea grandiflora and Qualea cordata (Vochysiaceae) using liquid chromatography coupled with ESIQToF-MS/MS. J. Braz. Chem. Soc. 24, 758-764.

Chakrabarti, A., Bonifaz, A., Gutierrez-Galhardo, M.C., Mochizuki, T., Li, S., 2015. Global epidemiology of sporotrichosis. Med. Mycol. 53, 3-14.

Chau, M.M., Kong, D.C., van Hal, S.J., Urbancic, K., Trubiano, J.A., Cassumbhoy, M., Wilkes, J., Cooper, C.M., Roberts, J.A., Marriott, D.J., Worth, L.J., 2014. Consensus guidelines for optimising antifungal drug delivery and monitoring to avoid toxicity and improveoutcomes in patients with hematological malignancy, 2014. Intern Med J. 44 (12b), 1364-1388.

Clinical and Laboratory Standards Institute (CLSI), 2008. Reference method for broth dilution antifungal susceptibility testing of yeasts. Approved standard. Document M27- A3. Wayne PA: Clinical Laboratory Standards Institute, Wayne, PA.

Cruz, M.C., Santos, P.O., Barbosa, A.M., Jr, de Mélo, D.L., Alviano, C.S., Antoniolli, A.R. Alviano, D.S., Trindade, R.C., 2007. Antifungal activity of Brazilian medicinal plants involved in popular treatment of mycoses. J. Ethnopharmacol. 111, 409-412.

de Paula e Silva, A.C., Oliveira, H.C., Silva, J.F., Sangalli-Leite, F., Scorzoni, L., FuscoAlmeida, A.M., 2013. Microplate alamar blue assay for Paracoccidioides susceptibility testing. J. Clin. Microbiol. 51, 1250-1252.

de Souza, C.P., Lucas, R., Ramadinha, R.H., Pires, T.B., 2016. Cryosurgery in association with itraconazole for the treatment of feline sporotrichosis. J. Feline Med Surg. 18 (2), 137-143.

Dutra, R.C., Campos, M.M., Santos, A.R., Calixto, J.B., 2016. Medicinal plants in Brazil: pharmacological studies, drug discovery, challenges and perspectives. Pharmcol. Res. 112, 4-29.

Ferreira, L.S., Gonçalves, A.C., Portuondo, D.L., Maia, D.C., Placeres, M.C., BatistaDuharte, A., Carlos, I.Z., 2015. Optimal clearance of Sporothrix schenckii requires an intact Th17 response in a mouse model of systemic infection. Immunobiology 220, 985-992.

Fuller, R.W., Westergaard, C.K., Collins, J.W., Cardellina, J.H., II, Boyd, M.R., 1999. Vismia phenones D-G, New Prenylated Benzophenones from Vismia cayennensis. J. Nat. Prod. 62, 67-69. 
Gaitán, I., Paz, A.M., Zacchino, S.A., Tamayo, G., Giménez, A., Pinzón, R., Cáceres, A Gupta, M.P., 2011. Subcutaneous antifungal screening of Latin American plant extracts against Sporothrix schenckii and Fonsecaea pedrosoi. Pharm. Biol. 49, 907-919.

Garcia, C.C., Guabiraba, R., Soriani, F.M., Teixeira, M.M., 2010. The development of antiinflammatory drugs for infectious diseases. Discov. Med. 10, 479-488.

Gonçalves, A.C., Maia, D.C., Ferreira, L.S., Monnazzi, L.G., Alegranci, P., Placeres, M.C., Batista- Duharte, A., Carlos, I.Z., 2015. Involvement of major components from Sporothrix schenckii cell wall in the caspase-1 activation, nitric oxide and cytokines production during experimental sporotrichosis. Mycopathologia 179, 21-30.

Green, L.C., Wagner, D.A., Glogowski, J., Skipper, P.L., Wishnok, J.S., Tannenbaum, S.R., 1982. Analysis of nitrate, nitrite, and $[15 \mathrm{~N}]$ nitrate in biological fluids. Anal. Biochem. 126, 131-138.

Guterres, K.A., de Matos, C.B., Osório, LdaG., Schuch, I.D., Cleff, M.B., 2014. The use of (1-3) $\beta$-glucan along with itraconazole against canine refractory sporotrichosis. Mycopathologia 177, 217-221.

Gutierrez-Galhardo, M.C; Freitas, D.F.S; do Valle, A.C.F; Francesconi, A.C. Clinical forms of human sporotrichosis and host immunocompetence. In: Carlos IZ ed. Sporotrichosis. New developments and future prospects. ISBN 978-3-319-11911-3. Springer International Publishing Switzerland. 2015 pp:73-82

Hussain, H., Hussain, J., Al-Harrasi, A., Saleem, M., Green, I.V., van Ree, T., Ghulam, A., 2012. Chemistry and biology of genus Vismia. Pharm. Biol. 50, 1448-1462.

Johann, S., Pizzolatti, M.G., Donnici, C.L., de Resende, M.A., 2007. Antifungal properties of plants used in Brazilian traditional medicine against clinically relevant fungal pathogens. Braz. J. Microbiol. 38, 632-637.

Kuete, V., Nguemeving, J.R., Beng, V.P., Azebaze, A.G.B., Etoa, F.X., Meyer, M., Bodo, B., Nkengfack, A.E., 2007. Antimicrobial activity of the methanolic extracts and compounds from Vismia laurentii De wild (Guttiferae). J. Ethnopharmacol. 109, $372-379$.

Kumar, S., Sharma, S., Chattopadhyay, S.K., 2013. The potential health benefit of polyisoprenylated benzophenones from Garcinia and related genera: ethnobotanical and therapeutic importance. Fitoterapia 89, 86-125.

Maia, D.C., Gonçalves, A.C., Ferreira, L.S., Manente, F.A., Portuondo, D.L., Vellosa, J.C., Polesi, M.C., Batista-Duharte, A., Carlos, I.Z., 2016. Response of cytokines and hydrogen peroxide to Sporothrix schenckii exoantigen in systemic experimental infection. Mycopathologia 181, 207-215.

Masoko, P., Picard, J., Eloff, J.N., 2005. Antifungal activities of six South African Terminalia species (Combretaceae). J. Ethnopharmacol. 99, 301-308.

Masoko, P., Picard, J., Howard, R.L., Mampuru, L.J., Eloff, J.N., 2010. In vivo antifungal effect of Combretum and Terminalia species extracts on cutaneous wound healing in immunosuppressed rats. Pharm. Biol. 48, 621-632.

Mora-Montes, H.M., Dantas Ada, S., Trujillo-Esquivel, E., de Souza Baptista, A.R. Lopes-Bezerra, L.M., 2015. Current progress in the biology of members of the Sporothrix schenckii complex following the genomic era. FEMS Yeast Res., 15, (fov065).

Negrini, Tde C., Ferreira, L.S., Alegranci, P., Arthur, R.A., Sundfeld, P.P., Maia, D.C., Spolidorio, L.C., Carlos, I.Z., 2013. Role of TLR-2 and fungal surface antigens on innate immune response against Sporothrix schenckii. Immunol. Invest. 42, 36-48.

Otang, W.M., Grierson, D.S., Ndipm, R.N., 2012. Phytochemical studies and antioxidant activity of two South African medicinal plants traditionally used for the management of opportunistic fungal infections in HIV/AIDS patients. BMC Complement. Altern. Med 12, 43.

Pochapski, M.T., Fosquiera, E.C., Esmerino, L.A., Dos Santos, E.B., Farago, P.V., Santos,
F.A., Groppo, F.C., 2011. Phytochemical screening, antioxidant, and antimicrobial activities of the crude leaves' extract from Ipomoea batatas (L.). Lam. Pharm. Mag. 7 (26), 165-170.

Portuondo, D.L., Batista-Duharte, A., Ferreira, L.S., Martínez, D.T., Polesi, M.C., Duarte, R.A., dePaula E Silva, A.C., Marcos, C.M., Almeida, A.M., Carlos, I.Z., 2016. A cell wall protein-based vaccine candidate induce protective immune response against Sporothrix schenckii infection. Immunobiology 221, 300-309.

Portuondo, D.L., Ferreira, L.S., Urbaczek, A.C., Batista-Duharte, A., Carlos, I.Z., 2015. Adjuvants and delivery systems for antifungal vaccines: current state and future developments. Med. Mycol. 53, 69-89.

Rubio, C.O., Cuellar, A.C., Rojas, N., Castro, H.V., Rastrelli, L., Aquino, R., 1999. A polyisoprenylated benzophenone from cuban própolis. J. Nat. Prod. 62, 1013-1015.

Sassá, M.F., Ferreira, L.S., Ribeiro, L.C., Carlos, I.Z., 2012. Immune response against Sporothrix schenckii in TLR-4-deficient mice. Mycopathologia 174, 21-30.

Seo, E.K., Wani, M.C., Wall, M.E., Navarro, H., Mukherjee, R., Farnsworth, N.R. Kinghorn, D., 2000. New bioactive aromatic compounds from Vismia guianensis. Phytochemistry 55, 35-42.

Singh, D.N., Verma, N., Raghuwanshi, S., Shukla, P.K., Kulshreshtha, D.K., 2008. Antifungal activity of Agapanthus africanus extractives. Fitoterapia 79, 298-300.

Stopiglia, C.D., da Rocha, Vianna, D., de Carvalho Meirelles, G., Teixeira, H., von Poser, G.L., Scroferneker, M.L., 2011. Antifungal activity of Pterocaulon species (Asteraceae) against Sporothrix schenckii. J. Mycol. Med. 21, 169-172.

Suffredini, I.B., Paciência, M.L.B., Nepomuceno, D.C., Younes, R.N., Varella, A.D., 2006. Antibacterial and cytotoxic activity of Brazilian plant extracts - Clusiaceae. Mem. Inst. Oswaldo Cruz. 101, 287-290.

Svetaz, L., Zuljan, F., Derita, M., Petenatti, E., Tamayo, G., Cáceres, A., Cechinel Filho, V., Giménez, A., Pinzón, R., Zacchino, S.A., Gupta, M., 2010. Value of the ethnomedical information for the discovery of plants with antifungal properties. A survey among seven Latin American countries. J. Ethnopharmacol. 127, 137-158.

Tamokou, Jde D., Tala, M.F., Wabo, H.K., Kuiate, J.R., Tane, P., 2009. Antimicrobial activities of methanol extract and compounds from stem bark of Vismia mubescens. J Ethnopharmacol. 124, 571-575.

Téllez, M.D., Batista-Duharte, A., Portuondo, D., Quinello, C., Bonne-Hernández, R., Carlos, I.Z., 2014. Sporothrix schenckii complex biology: environment and fungal pathogenicity. Microbiology 160, 2352-2365.

Uma, K., Huang, X., Kumar, B.A., 2016. Antifungal effect of plant extract and essential oil. Chin. J. Integr. Med. Sep, 3. http://dx.doi.org/10.1007/s11655-016-2524-z.

Vizcaya, M., Morales, A., Rojas, J., Nunez, R., 2012. A review on the chemical composition and pharmacological activities of Vismia genus (Guttiferae). Bol. Latinoam. Y. Del. Caribe Plantas Med. Y. Aromáticas 11 (1), 12-34.

Vukics, V., Guttman, A., 2010. Structural characterization of flavonoid glycosides by multistage mass spectrometry. Mass Spec. Rev. 29, 1-6.

Wabo, H.K., Kouam, S.F., Kronh, K., Hussain, H., Tala, M.F., Tane, P., Ree, T.V., Hu, Q., Schulz, B., 2007. Prenylated anthraquinones and other constituents from the seeds of Vismia laurentii. Chem. Pharm. Bull. 55, 1640-1642.

Waller, S.B., Madrid, I.M., Faria, R.O.D., Cleff, M.B., Mello, J.R.B.D., Meireles, M.C.A., 2016. Anti-Sporothrix spp. activity of medicinal plants. Braz. J. Pharm. Sci. 52 (2), 221-237.

Wang, J.Y., Yuan, Y., Chen, X.J., Fu, S.G., Zhang, L., Hong, Y.L., You, S.F., Yang, Y.Q. 2016. Extract from Eucommia ulmoides Oliv. Ameliorates Arthritis via Regulation of Inflammation, synoviocyte proliferation and osteoclastogenesis in vitro and in vivo. J. Ethnopharmacol., (pii: S0378-8741(16)31241-7). 